University of Nebraska - Lincoln

DigitalCommons@University of Nebraska - Lincoln

\title{
Formation of Polyphenol-Denatured Protein Flocs in Alcohol Beverages Sweetened with Refined Cane Sugars
}

\author{
Gillian Eggleston \\ USDA-ARS, gillian.eggleston@ars.usda.gov \\ Alexa Triplett \\ USDA-ARS, Alexa.Triplett@ars.usda.gov
}

Follow this and additional works at: https://digitalcommons.unl.edu/usdaarsfacpub

Eggleston, Gillian and Triplett, Alexa, "Formation of Polyphenol-Denatured Protein Flocs in Alcohol Beverages Sweetened with Refined Cane Sugars" (2017). Publications from USDA-ARS / UNL Faculty. 1765.

https://digitalcommons.unl.edu/usdaarsfacpub/1765

This Article is brought to you for free and open access by the U.S. Department of Agriculture: Agricultural Research Service, Lincoln, Nebraska at DigitalCommons@University of Nebraska - Lincoln. It has been accepted for inclusion in Publications from USDA-ARS / UNL Faculty by an authorized administrator of DigitalCommons@University of Nebraska - Lincoln. 
Article

\author{
Formation of Polyphenol-Denatured Protein Flocs in \\ Alcohol Beverages Sweetened with Refined Cane Sugars \\ Gillian Eggleston, and Alexa Triplett
}

J. Agric. Food Chem., Just Accepted Manuscript • DOI: 10.1021/acs.jafc.7b03185 • Publication Date (Web): 10 Oct 2017

\title{
Just Accepted
}

"Just Accepted" manuscripts have been peer-reviewed and accepted for publication. They are posted online prior to technical editing, formatting for publication and author proofing. The American Chemical Society provides "Just Accepted" as a free service to the research community to expedite the dissemination of scientific material as soon as possible after acceptance. "Just Accepted" manuscripts appear in full in PDF format accompanied by an HTML abstract. "Just Accepted" manuscripts have been fully peer reviewed, but should not be considered the official version of record. They are accessible to all readers and citable by the Digital Object Identifier (DOI®). "Just Accepted" is an optional service offered to authors. Therefore, the "Just Accepted" Web site may not include all articles that will be published in the journal. After a manuscript is technically edited and formatted, it will be removed from the "Just Accepted" Web site and published as an ASAP article. Note that technical editing may introduce minor changes to the manuscript text and/or graphics which could affect content, and all legal disclaimers and ethical guidelines that apply to the journal pertain. ACS cannot be held responsible for errors or consequences arising from the use of information contained in these "Just Accepted" manuscripts. 
1

3

4

5

6

7

8

9

10

11

12

13

14

15

16

17

18

19

20

12

3

14

15

6

8

9

20

\title{
Formation of Polyphenol-Denatured Protein Flocs in Alcohol Beverages
}

Sweetened with Refined Cane Sugars

\author{
Gillian Eggleston*广and Alexa Triplett*
}

*USDA-ARS-Southern Regional Research Center

1100 Robert E. Lee Boulevard

New Orleans, LA 70124, USA

${ }^{\dagger}$ gillian.eggleston@ars.usda.gov

Tel: 504-286-4446 
21 ABSTRACT: The sporadic appearance of floc from refined, white cane sugars in alcohol 22 beverages remains a technical problem for both beverage manufacturers and sugar refiners.

23 Cane invert sugars mixed with $60 \%$ pure alcohol and water increased light scattering by up to $24 \sim 1000$-fold. Insoluble and soluble starch, fat, inorganic ash, oligosaccharides, Brix, and $\mathrm{pH}$ were 25 not involved in the prevailing floc formation mechanism. Strong polynomial correlations existed 26 between the haze floc and indicator values I.V. (color at $420 \mathrm{~nm} \mathrm{pH} \mathrm{9.0/color} \mathrm{at} \mathrm{pH} 4.0-$ an 27 indirect measure of polyphenolic and flavonoid colorants) $\left(\mathrm{R}^{2}=0.815\right)$ and protein $\left(\mathrm{R}^{2}=0.819\right)$ 28 content of the invert sugars. Ethanol induced denaturation of the protein exposed hydrophobic 29 polyphenol binding sites that were further exposed when heated to $80{ }^{\circ} \mathrm{C}$. A tentative 30 mechanism for floc formation was advanced by molecular probing with a haze (floc) active 31 protein and polyphenol as well as polar, non-polar, and ionic solvents.

33 KEYWORDS: alcohol beverage floc; refined cane sugar; haze active protein; haze active 34 polyphenol; denatured protein; 


\section{2}

\section{INTRODUCTION}

The sporadic appearance of unattractive floc from refined, cane (white) sugars in alcoholic beverages is a concern to both beverage manufacturers and sugar refiners. Although floc is a quality parameter that will not impact health and nutritional status of the beverage, the consumer expects the beverage to be clear and will most likely be deterred from purchasing the beverage. Furthermore, floc formation can limit the shelf-life of the beverage. The visible defect may be particulate and sedimentary or "woolly" and suspended in the beverage or precipitated. ${ }^{1}$ Cohen et al. $^{2}$ reported that, while all acid beverage floc (ABF) forming sugars also develop a floc on the addition of ethanol, not all alcohol haze forming sugars develop ABF. With the declining use of high fructose corn syrup as a beverage sweetener in recent years, floc from either beet or cane sugars, inverted or non-inverted, remains a technical problem that is not easily managed. Typically, refined beet sugars are less prone to cause haze and the primary cause has been attributed to saponins. $^{1,3}$ For refined cane sugars, however, no definitive cause has been attributed to any one quality parameter. Silica, polysaccharides, ${ }^{4}$ protein, ${ }^{4-5}$ and fats/waxes have all been implicated (see reviews ${ }^{1,6}$ ). Polysaccharides in cane sugar can include dextran formed from microbial deterioration (levan and sarkaran polysaccharides are also formed from specific microbial deteriorations in a few parts of the world, particularly dry areas), starch, indigenous cane polysaccharide ISP (arabinoglucan), and small amounts of soluble cellulose and pectin. ${ }^{1}$ Clarke et al. ${ }^{4}$ put forward a mechanism for acid beverage floc that incorporated a coacervate of a positively charged protein interacting with a negatively charged ISP. It has been more recently reported by McKee et al. ${ }^{7}$ for acid beverage floc formation only, that when a high $(>3.2)$ color indicator value I.V. (color absorbance ratio at $420 \mathrm{~nm}$ of the sugar solution at $\mathrm{pH} 9.0$ to $\mathrm{pH} 3.0$ ) is present in cane refined sugar there is a strong likelihood that acid beverage floc will form, but 
65 no explanation has been put forward. As high I.V. values are indicators of polyphenolic and 66 flavonoid colorants that naturally occur in sugarcane, ${ }^{8-9}$ these may be involved with floc

67 formation or they may be indirectly involved. Polyphenolic-protein haze flocs are known to 68 form in beer, wine, cider, and fruit juices. ${ }^{10}$ Iciek et al., ${ }^{3}$ however, reported that the use of I.V. 69 values to predict acid beverage floc formation from cane sugars has not been totally reliable as 70 outliers have been found and stated further studies were required.

71 Lemos et al. ${ }^{6}$ studied twenty-one refined cane sugars from Brazil for their formation of 72 alcohol flocs at 55-89\% v/v ethanol, and reported that total starch and dextran positively 73 correlated with alcohol floc formation. They used a starch method (ICUMSA GS1-16) that is 74 now known to only measure soluble starch and provides no information of the amount of 75 insoluble starch present, and the Haze dextran method used to determine dextran is not specific 76 to dextran and can measure other haze forming compounds as well. Because insoluble starch has 77 not been previously detected before by commonly used starch methods, its contribution to 78 beverage floc formation has never been realized. Fortunately, a new USDA research method has 79 now been developed by Cole et al. ${ }^{11}$ to measure total, insoluble and soluble starch, utilizing 80 microwave-assisted probe sonication.

81 Alcohol beverages are high value-added products with an enormous international market.

82 Such products are often sweetened with white, refined sugars sourced from around the world; the 83 sugars can be sucrose or invert sugars. Alcohol beverage manufacturers can occasionally 84 encounter batches of sugars that cause unwanted floc in their alcoholic products. Unfortunately, 85 there are no rigorous specifications for the prediction of floc from refined cane sugars and, in 86 particular, unwanted false negative results. This may be because there are multiple causes and/or 87 because the underlying reasons for floc formation are still not completely known. At this present 
88

89

90

91

92

93

94

95

96

97

98

99

100

\section{1}

time, some alcohol beverage manufacturers estimate floc formation from batches of sugar by creating a $60 \%$ ABV (alcohol beverage volume) sugar base, which is simply invert sugar (or other sugar) mixed with pure alcohol and water to a $60 \% \mathrm{ABV}$ target. If after $30 \mathrm{~min}$ the fortified sugar turns hazy $(\mathrm{NTU} \geq 2.0$ ) it is considered to be unstable. This fortified sugar must stand for $24 \mathrm{~h}$ before it is filtered to remove flocs. Once flocs are removed the now clear, fortified sugar solution can be used to make flavored beverage products.

This study was undertaken to improve understanding of the root cause or causes of floc formation in alcoholic beverages sweetened with refined cane sugars. Another long-term goal of the study is to underpin the development of rigorous specifications for the measurement of alcohol haze formation.

\section{MATERIALS AND METHODS}

Chemicals. All chemicals were analytical grade. Dimethylfromamide (DMF), 1,4-dioxane, tannic acid, gelatin (Type B) from bovine skin, tannic acid, triethanolamine, dioxane, and dimethylformamide (DMF) were obtained from Sigma-Aldrich (St. Louis, MO, USA). Deionized water of $<18 \mathrm{ohm}$ resistance) was used in sample preparation. Absolute ethanol was from Koptec (King of Prussia, PA, USA). Sodium chloride was from J. T. Baker (Phillipsburg, NJ, USA). Dextranase sourced from Chaetomium erraticum was produced by Amano Enzymes, Inc. (Gifu, Japan) and obtained from Alma sugarcane factory (Lakeland, LA, USA), and had an activity of 52,000 DU/mL. An intermediate-temperature (IT) stable amylase from Bacillus amyloliquefaciens was produced by and obtained from Amano Enzymes, Inc. (Gifu, Japan) (activity of $447 \mathrm{KRAU} / \mathrm{g}$ ). A high temperature (HT) stable amylase produced by Novozymes 
110 (Franklinton, NC, USA) was sourced from Bacillus licheniformis and obtained from Brenntag 111 (Houston, TX, USA), (activity of $400 \mathrm{KRAU} / \mathrm{g}$ ).

112 Beverages. Commercial invert sugars ( 75 Brix syrup) from various refinery sources 113 (denoted by upper case letters), and 60\% ABV unfiltered and filtered sugar bases produced from 114 the invert sugars, were obtained from a large North American alcohol beverage manufacturer. 115 The $60 \%$ ABV sugar base $(1 \mathrm{~L})$ was created by adding invert sugar syrup $(260 \mathrm{~g})$ to $780 \mathrm{~mL}$ of $11677 \%$ ethanol plus $30 \mathrm{~mL}$ of de-ionized water. This $60 \%$ ABV sugar base (unfiltered) was left for $11724 \mathrm{~h}$ by the beverage manufacturer to approximately estimate if any floc will form. The 118 unfiltered $60 \% \mathrm{ABV}$ was then pressure filtered through diatomaceous earth to form the filtered $11960 \%$ ABV sugar base.

120 Stock Solutions. Tannic acid stock solution $(5,000 \mathrm{ppm})$ was prepared by dissolving tannic 121 acid in ethanol (20\% of final stock solution volume) and making to the volume with de-ionized 122 water. Gelatin stock solution was prepared daily by dissolving protein $(5,000 \mathrm{ppm})$ in de-ionized 123 water.

124 Floc Measurements by Haze. Light scattering measurements were undertaken with a Hach 125 Model 2000N nephalometer (Hach, Loveland, CO). Samples containing flocs were gently 126 shaken first before measurement. Results were expressed in nephelometric turbidity units 127 (NTU).

128 Particle Size Analysis. This was conducted on a Malvern Zetasizer Nano ZS90 129 (Worcestershire, UK). Samples were inverted gently to ensure even mixing. Unfiltered 60\% 130 ABV samples (1 to $1.5 \mathrm{~mL}$ ) were analyzed. The parameters of the Zetasizer software (ver. 7.11) 
131 were established for the refractive index of ethanol. Triplicate samples were run, and eleven 132 scans were run per replicate.

Effect of a Haze-Active Protein and Polyphenol. Floc was produced by adding gelatin $134(5,000 \mathrm{ppm}$; haze-forming protein) or tannic acid (5,000 ppm; haze-forming polyphenol) to the 135 test $60 \% \mathrm{ABV}$ solution $(20 \mathrm{~mL}$ in a $100 \mathrm{~mL}$ beaker). The samples were incubated for $30 \mathrm{~min}$ at $13625^{\circ} \mathrm{C}$. water bath at $80{ }^{\circ} \mathrm{C}$; the $80{ }^{\circ} \mathrm{C}$ samples were cooled to $25{ }^{\circ} \mathrm{C}$ before measuring the haze. The haze of the samples at room temperature $\left(25^{\circ} \mathrm{C}\right)$ were also measured and compared. was heated to $80{ }^{\circ} \mathrm{C}$ or $100{ }^{\circ} \mathrm{C}$ for $30 \mathrm{~min}$, and then allowed to cool to $25^{\circ} \mathrm{C}$. The treated protein enzyme at $0.1,0.25,0.50,0.75$, or $1.0 \mathrm{~mL}$ was added to tannic acid $(500 \mathrm{ppm} ; 5 \mathrm{~mL})$ in $20 \mathrm{~mL}$ of de-ionized water in a $60 \mathrm{~mL}$ test-tube and gently mixed. Care was also taken to gently shake the 144 treated enzyme before adding it to the final solution. The samples were incubated for $30 \mathrm{~min}$ at $14525{ }^{\circ} \mathrm{C}$ before turbidity was measured. Blank samples were also prepared that did not contain any 146 tannic acid solution, to take into account the Haze created by the denatured protein alone. The 147 final Haze (NTU) measurement was NTU sample $-N^{2} U_{\text {blank }}$.

Effect of Solvent Experiments. To $20 \mathrm{~mL}$ of unfiltered $60 \%$ ABV samples, 0, 2, 4, and 8 $\mathrm{mL}$ of either de-ionized water, absolute ethanol, dioxane, $\mathrm{DMF}$, or $20 \% \mathrm{NaCl}$ solution were 150 added and gently mixed. This resulted in solutions containing $0,10,20$, and $40 \%$ solvent. The 151 haze of the resulting solution left at $25^{\circ} \mathrm{C}$ (room temperature) for $30 \mathrm{~min}$ was then measured. 
Insoluble and Soluble Starch. Samples were analyzed for total, soluble, and insoluble

153 starch using the microwave-assisted sonication/iodometric USDA Research method. ${ }^{11}$ Invert

154 syrups were first adjusted to $\sim 15$ Brix before analyses and starch was assayed in triplicate;

155 concentrations are quoted as average ppm on a Brix basis.

Brix (\% dissolved refractometric solids), pH, Ash, and Fat. Brix was measured using an

157 Index Instruments (Kissimmee, FL) TCR 15-30 temperature controlled refractometer accurate to

$158 \pm 0.01$ Brix, and results expressed as an average of triplicates. The $\mathrm{pH}$ was measured on a 159 Metrohm Brinkman 716 DMS Titrino (Riverview, FL, USA) with a Mettler Toledo (Columbus, $160 \mathrm{OH}, \mathrm{USA})$ xerolyte electrode. Inorganic ash was measured according to method AOAC 900.12; 161 the weighed samples were ashed at $600{ }^{\circ} \mathrm{C}$. Fat analysis followed MWL FO 08 method based on 162 AOAC 922.06 method. The homogenized sample was treated with $\mathrm{HCl}$ and washed twice with 163 petroleum ether and diethyl ether. Both ash and fat were expressed as \% on a wet weight basis 164 and results are averages of triplicate analysis.

Color and Indicator Values. Color was measured as the absorbance at $420 \mathrm{~nm}$ and 166 calculated according to the official ICUMSA method GS2/3-9 (1994) with slight modifications.

167 The invert syrup samples and 60\% ABV unfiltered and filtered samples were not initially Brix 168 adjusted. Samples $(\sim 5 \mathrm{~mL})$ were diluted in triethanolamine/hydrochloric acid buffer $(5 \mathrm{~mL} ; \mathrm{pH}$ 169 7) and filtered through a $0.45 \mu \mathrm{m}$ filter. Color was also measured at $\mathrm{pH} 3.0,4.0$, and 9.0 by first 170 adjusting the buffer with $\mathrm{HCl}$ and $\mathrm{NaOH}$ solutions, respectively. The Indicator Value (I.V.) was 171 measured as both the ratio of color at $\mathrm{pH} 9.0$ /color at $\mathrm{pH} 4.0$ as well as color at $\mathrm{pH} 9.0 /$ color at $172 \mathrm{pH}$ 3.0. Results are expressed as an average of triplicates.

173 Protein. The presence of protein was confirmed qualitatively by scanning the invert sugar in 174 a Beckman DU-64 UV/Vis Spectrophotometer between $220-350 \mathrm{~nm}$. Protein was present as a 
175 peak at $280 \mathrm{~nm}$ due to the presence of select amino-acids (tyrosine and particularly tryptophan 176 and phenylalanine). Once protein presence was confirmed it was assayed using a Bio-Rad 177 protein colorimetric assay (Bio-Rad Laboratories, Hercules, CA, USA) based on the Bradford

178 dye-binding method. ${ }^{12}$ Bovine serum albumen (BSA) standard was used to create the standard 179 curve at $595 \mathrm{~nm}$ absorption. This method is based on the dye binding primarily to basic 180 (particularly arginine) and aromatic amino-acids. Results are expressed as an average of 181 duplicates.

Dextran. The Rapid Dextran Test (Ecolab, KS, USA) was used to measure monoclonal 183 antibody dextran. A conversion factor was calculated for each batch of antibody used. Results 184 are expressed as an average of duplicates.

Oligosaccharides measured using ion chromatography with integrated pulsed amperometric detection (IC-IPAD). An oligosaccharide fingerprint chromatogram (up to 12

187 DP) of each sample was obtained by using a strong $\mathrm{NaOH} / \mathrm{NaOAc}$ gradient over $40 \mathrm{~min},{ }^{13}$ using 188 CarboPac PA1 analytical and guard columns (Dionex Corp., Sunnyvale, CA, USA) at $25^{\circ} \mathrm{C}$. All 189 samples were adjusted to 7.0 Brix prior to comparison.

Statistics. Pearson correlation coefficients were calculated to investigate relationships 191 among the different chemical and physical parameters using Microsoft Excel $2013^{\mathrm{TM}}$. Statistical 192 differences between parameters at the 5\% probability level were calculated by the Students t-test 193 also using Microsoft Excel $2013^{\mathrm{TM}}$. 
Floc Formation by Cane Invert Sugars. Four invert sugars (A to D) produced from sugarcane refined sugars and known to cause alcohol floc formation, were first studied. Floc (haze) formation was measured by light scattering nephelometry, which is used routinely in the quality control of beverages, including alcohol beverages such as ciders and beers. ${ }^{10}$ The haze of the invert sugars was very low, i.e., between 0.018 to $0.024 \mathrm{NTU}$, and bore no relationship to the floc formed on the addition of ethanol (Table 1). Flocs formed in the unfiltered $60 \% \mathrm{ABV}$ samples (invert sugar mixed with pure alcohol and water to a $60 \% \mathrm{ABV}$ target) increased light scattering by up to $\sim 1000$-fold, i.e., 11.3 to 20.5 NTU greater than the initial invert sugars. The flocs formed were white and fluffy and eventually precipitated to the bottom of the bottle. As expected, when the $60 \%$ ABV samples were filtered the NTU values markedly decreased (Table $1)$.

The acidic $\mathrm{pH}$ values of the initial invert sugars varied from 3.85 to 5.77 (Table 1). The alcohol manufacturer who provided the samples does not adjust the $\mathrm{pH}$ of the sugar when producing beverages, but many alcohol beverages are between $\mathrm{pH} 3.0$ and 4.0. As seen in Table 1, the addition of ethanol to the sugars increased the $\mathrm{pH}$ most likely because of the diluting out of acids, whereas the filtering of these solutions to remove the flocs had negligible effect on the $\mathrm{pH}$. The initial $\mathrm{pH}$ of the invert sugars strongly affected the $\mathrm{pH}$ of the final filtered $\mathrm{ABV}$ solutions $\left(\mathrm{R}^{2}=0.975 ; \mathrm{y}=0.484 \mathrm{x}+3.424\right)$. Neither the $\mathrm{pH}$ nor the Brix values were found to have any relationship on floc formation.

Chemical Composition Analyses. At the beginning of this study, the cause of floc formation in alcohol beverages sweetened with refined cane sugars was not known so initial research focused on a few possibilities, including starch, dextran, oligosaccharides, fat, ash, protein, color, etc. In this study, none of the invert sugars contained any soluble or insoluble 
219

220

221

222

223

224

225

226

227

228

229

230

231

232

233

234

235

236

237

238

239

240

241

starch (Table 2), which strongly indicated that no starch physical forms are involved in the floc formation mechanism. Nevertheless, this does not preclude that starch molecules could not be entrained or co-precipitated with the precipitated floc. Lemos et al. ${ }^{6}$ showed that soluble starch can cause the formation of flocs in ethanol solution although dextran had a greater effect. In this study, high molecular weight dextran was measured in the samples using a specific monoclonal antibody method, and results are listed in Tables 2 and 3. All the invert sugars contained dextran but there was not a strong relationship between dextran and haze floc formation. Nevertheless, the dextran content was markedly reduced in the $60 \% \mathrm{ABV}$ samples suggesting it became insoluble in the ethanol and may have associated with the floc, although it was not involved in the initial mechanism of floc formation. Fat concentrations of 0.3 to $0.5 \%$ were measured in the invert sugars which may reflect wax from the surface of sugarcane stalks. The fat concentrations were reduced to negligible levels $(<0.1 \%)$ in the unfiltered $60 \%$ ABV samples, which are less than the $0.1 \%$ limit of the method of analysis used. Thus fat was dissolved in the ethanol and not involved in floc formation (Table 2). Additionally, inorganic ash concentrations were found to have no relationship with floc formation (Table 2). Fingerprint oligosaccharide chromatograms of the unfiltered $60 \%$ ABV samples are illustrated in Figure 1. The samples contained very few oligosaccharides which were not related to floc formation. The chromatograms of the initial invert sugars and filtered samples (not shown) were very similar to the unfiltered samples.

The color of the initial four cane invert samples A to D as well as three more (E to $G$ ) sent from the alcohol manufacturer was measured at $\mathrm{pH} 3.0,4.0,7.0$, and 9.0, and the color Indicator Value I.V. was calculated as the ratio of color at $\mathrm{pH} 9.0$ /color at $\mathrm{pH} 4.0$ as well as $\mathrm{pH} 9.0$ color/color at $\mathrm{pH}$ 3.0. As expected, colors at $\mathrm{pH} 4.0$ and 7.0 were lower than at $\mathrm{pH} 9.0$, because color intensity depends on the solution $\mathrm{pH}$ due to changes in molecular structure, ionization, and 
242 association-dissociation equilibria ${ }^{15}$; the changes are not linear and color intensity changes most 243 steeply in the $\mathrm{pH}$ range 6.0 to 8.0 (Tables 2 and 3).

244 None of the individual colors measured at the various $\mathrm{pHs}$ exhibited a strong relationship 245 with floc formation (NTU), although a moderate correlation $\left(\mathrm{R}^{2}=0.679\right)$ existed for color at $\mathrm{pH}$ 246 9.0. It is well known that cane derived colorants, e.g., flavonoids and polyphenols, are sensitive 247 to the higher $\mathrm{pH}$ values while process derived colorants are not. ${ }^{14}$ In contrast, a strong 248 polynomial relationship $\left(\mathrm{R}^{2}=0.815\right)$ existed between the I.V. (color ratio at $\left.\mathrm{pH} 9.0 / \mathrm{pH} 4.0\right)$ values 249 of the invert sugars with haze turbidity formation (Figure 2). Thus, floc formation became 250 progressively worse with increased values of I.V. Since the two I.V. values, i.e., color ratio at $251 \mathrm{pH} 9.0 / \mathrm{pH} 4.0$ and $\mathrm{pH} 9.0 / \mathrm{pH} 3.0$, were strongly related $\left(\mathrm{R}^{2}=0.952 ; \mathrm{y}=1.1161 \mathrm{x}-0.1425\right)$, most 252 likely both could be used to indicate floc formation. These results confirmed the findings of 253 McKee et al. ${ }^{7}$ for acid beverage flocs. It must be noted, however, that the I.V. (pH 9.0/pH 3.0) 254 values which correlated strongly with floc formation in this study, i.e., 1.27 to 1.54 , were not in 255 the range reported to predict acid beverage floc formation with white, refined cane sugars. ${ }^{7}$ 256 Moreover, McKee et al. ${ }^{7}$ observed that I.V. values $<2.1$ indicated a low floc potential for acid 257 beverage flocs. This suggests that much lower concentrations of polyphenolic colorants are 258 involved in the formation of alcohol beverage flocs most likely because of the addition of 259 ethanol. It is well known that sugarcane juice contains a complex mixture of polyphenolic and 260 phenolic flavonoid colorants that are monomeric and sensitive to $\mathrm{pH}$. The major polyphenols in 261 sugarcane are caffeic, chlorogenic, and coumaric acids. ${ }^{9}$ The predominant flavonoids are tricin, 262 naringenin, luteolin, and apigenin. ${ }^{8-9}$ Flavonoids are water soluble and at acid $\mathrm{pH}$ are non263 ionized. 
To qualitatively determine the presence of protein in all the cane invert sugars $A$ to $G$ and

265

266

267

268

269

270

271

272

273

274

275

276

277

278

279

280

281

282

283

284

285

their corresponding 60\% ABV unfiltered solutions, they were first scanned between 220 and 350

$\mathrm{nm}$, and all showed a protein peak at $280 \mathrm{~nm}$. As a consequence, they were all subsequently quantitatively analyzed for protein using a dye-binding method, ${ }^{12}$ and results are also listed in Tables 2 and 3. The protein levels in the invert sugars were very low ranging from 0.11 to 0.60 $\mu \mathrm{g} / \mathrm{mL}$ (ppm). Naidoo and Simpson ${ }^{5}$ reported that higher levels, i.e., $>2.00 \mu \mathrm{g} / \mathrm{mL}$, of protein in refined cane sugars assayed with a protein method also based on the Bradford dye-binding method, predicted that acid beverage flocs would form. Similar to the I.V. values (Figure 2), the protein had a polynomial relationship $\left(\mathrm{R}^{2}=0.819\right)$ with haze (floc) formation, indicating that floc formation became progressively worse with increased in protein concentrations and that protein was somehow involved in floc formation (Figure 3).

Small amounts of protein naturally occur in sugarcane juice ${ }^{4}$ including invertase and diastase enzymes. ${ }^{16}$ In addition, proteins as industrial enzymes are applied during sugar manufacture especially at the sugarcane factory. Amylases are often routinely added to degrade starch and dextranase is occasionally added to degrade dextran when it is present from the deterioration of sugarcane. ${ }^{13}$ Floc formation in other alcohol beverages, i.e., beer, has also been reported to be affected by proteins such as proteases added during beer processing. ${ }^{10}$ Not all proteins, however, are haze-active and contribute to floc formation. Proteins that readily interact and precipitate with polyphenols are generally large, have high proline (a non-polar, hydrophobic amino acid) content, and lack secondary or tertiary structure, i.e., are partially or fully denatured. ${ }^{17}$ Prolines are known to be involved with non-specific interactions primarily via ring stacking with their prolyl residues and with a preference for Pro-Pro repeats. ${ }^{18}$ It must also be noted that different 
286 polyphenols and tannins have been reported to show variations in interaction with a given 287 protein. $^{19}$

288 The Bradford protein assay used in this study is based on dye-binding primarily to basic, 289 particularly arginine, and aromatic amino-acids, which means it is not as sensitive to proline. 290 Arginine, however, has been reported to interact with polyphenol flavonoids, but to a lesser 291 extent than proline. ${ }^{18}$ Furthermore, the protein assay was calibrated using the globular protein 292 bovine serum albumen (BSA) which is known to have specific poly-phenol binding cavities. ${ }^{20} \mathrm{~A}$ 293 protein assay which is more sensitive to proline may have provided protein concentrations in the 294 cane invert sugars that had an even stronger relationship with floc formation than what was 295 found in this study (Table 2 and Figure 3). To the best knowledge of the authors no such 296 proline-sensitive protein assay has been developed yet.

297 As shown in Tables 2 and 3, the protein concentrations increased markedly in the unfiltered $29860 \%$ ABV solutions when compared to the initial invert sugars. This can be explained by the 299 Bradford dye-binding protein assay used. Ethanol at high concentrations such as the $60 \%$ in this 300 studies' ABV solutions, is known to induce and accelerate the denaturation of proteins. ${ }^{21}$ Partial 301 or full denaturation of the protein will have exposed additional polyphenol binding sites 302 including proline and to a lesser extent other amino acids such as phenyalanine, tyrosine, 303 arginine that have also been suggested to interact with polyphenol flavonoids. ${ }^{18}$ Denaturation of 304 the protein by ethanol may also have reduced the proximity of bulky amino acids that were near 305 to potential polyphenol binding sites and, therefore, increased accessibility. ${ }^{22}$ As a consequence, 306 since the Bradford dye-binding assay is based on binding to arginine and aromatic amino acids 307 more protein was detected. 
Downstream sugar factory and refinery processes, e.g., evaporation and crystallization, are

309

310

311

312

313

314

315

316

317

318

319

320

321

322

323

324

325

326

327

328

329

330

operated at elevated temperatures and are expected to partially or fully denature proteins. Furthermore, many sugar refinery processes have been reported ${ }^{4}$ to reduce or remove the amount of protein in processing streams. Nevertheless, protein can still be detected in refined sugars ${ }^{4}$ albeit at very low concentrations, and high temperature stable amylases have been known to cause carry-over (residual) amylase activity in refined sugars. ${ }^{23}$ Clarke et al., ${ }^{4}$ reported that sugarcane protein in refined sugars contained proline $(4 \%)$. Proline is also one of the major amino acid constituents (7\%) of dextranase enzymes sourced from Chaetomium gracile and Chaetomium erraticum fungi ${ }^{24}$ which are added at factories. Proline $(3 \%)$ is also contained in amylase proteins produced from Bacillus subtilis, Bacillus amyloliquefaciens, and Bacillus

licheniformis bacteria ${ }^{25}$ which are added at the factory. Furthermore, Clarke et al. ${ }^{4}$ reported that "it has been observed, in attempts to treat floccing sugars with enzymes, that the addition of any protein, e.g., amylase, pectinase, dextranase, to a sugar solution enhanced floc formation". To confirm that dextranase and amylase proteins could be involved with polyphenol-protein interactions, they were reacted with tannic acid (TA), a very haze-active polyphenol that is known to combine with haze-active protein to form a floc that can be measured by light scattering nephelometry ${ }^{14}$ (Table 4$)$. At very low volumes, dextranase $(0.281 \%$ protein) formed floc with TA as did IT stable amylase (Bacillus amyloliquefaciens; $2.235 \%$ protein) and especially HT stable amylase (Bacillus licheniformis; $1.541 \%$ protein).

\section{Relative Levels of Haze-Active Proteins and Polyphenols in Cane Invert Sugars. Since} the compositional analyses results suggested polyphenolic I.V. colorants and proteins may be involved in floc formation these were further investigated. Estimates of the relative amounts of haze-active proteins in the $60 \%$ ABV samples were made by adding tannic acid (TA). 
331 Conversely estimates of the relative amounts of "sensitive" or haze-active polyphenolics in the $33260 \%$ ABV samples were made by adding bovine gelatin, a very haze-active protein ${ }^{26}$ that 333 contains $16 \%$ proline, $^{27}$ and known to combine with haze-active polyphenolics. No $\mathrm{pH}$ 334 adjustments were undertaken in these experiments which were conducted at $25{ }^{\circ} \mathrm{C}$. The results 335 for the invert sugars are listed in Table 5. A beet invert sugar (control) was included in this study 336 which did not form any haze, but showed a very small increase in haze as a result of the addition 337 of both tannic acid and particularly protein (Table 5). Thus the beet invert sugar must contain 338 very small amounts of haze-active protein and slightly more haze-active polyphenols. The initial 339 I.V. value of the beet invert was 1.13 which was low compared to values for cane sugars (see 340 Table 3), but as the value was greater than 1.0 it confirmed that the beet invert sugar contained a 341 very small amount of polyphenol colorants. Such natural colorants most likely came from the 342 beet leaves and tuberous root. The beet invert sugar also contained a very small amount of 343 protein $(0.04 \mu \mathrm{g} / \mathrm{mL})$ detected by the Bradford dye-binding protein assay, ${ }^{12}$ which confirmed that 344 haze-active protein was present.

345 Results listed in Table 5 also showed that cane invert sugar D contained some haze-active 346 protein since haze was formed on the addition of tannic acid. The reduced value at $500 \mathrm{ppm}$ of 347 tannic acid is due to dilution because the additive was added by volume. In comparison, the 348 addition of gelatin to sugar D caused a decrease in floc formation indicating this sugar had 349 negligible amounts of polyphenols or that the polyphenols were all already bound to sites on the 350 sugar's protein. Invert sugars A and C did not seem to contain any available haze-active protein 351 that could bind with tannic acid because the addition of this haze-active polyphenol had no effect 352 (Table 5). Cane invert sugar $\mathrm{C}$ had increased haze formation on the addition of gelatin (the 353 reduced value at $500 \mathrm{ppm}$ of gelatin is due to dilution because the additive was added by 
354 volume) indicating not all of its polyphenolic colorants were bound. Beers are known to contain 355 a considerable amount of haze-active protein and very little haze-active polyphenol, whereas 356 commercial apple juices are just the opposite. ${ }^{8}$ However, the highest hazes in alcohol beverages 357 have been reported to depend on the ratio of haze-active protein to haze-active polyphenol. ${ }^{26}$ 358 Moreover, different polyphenols and tannins can also show variations in interactions with a 359 given protein. ${ }^{19}$

Nature of the Floc Interactions. The nature of polyphenolic-protein interactions has been the subject of many studies because they are involved in floc formation in other alcohol 362 beverages ${ }^{10,26}$ and also because phenolic compounds in foods are of great interest for their health 363 and dietary benefits. ${ }^{28}$ For example, proteins are being used in foods to complex with bitter and 364 astringent flavonoids. ${ }^{18}$ It is generally accepted that the polyphenol-protein interaction in 365 solution is a reversible interaction leading to an equilibrium between the soluble 366 protein/polyphenol complexes and the reactants. ${ }^{19}$ These soluble complexes may reach a size 367 where they are no longer soluble and this creates a floc. In turn, the flocs then may aggregate or 368 they may undergo changes resulting in precipitation/sedimentation. ${ }^{19}$

369 Heating of unfiltered $60 \%$ ABV samples recreated in the laboratory from the initial invert 370 sugars was undertaken at $80{ }^{\circ} \mathrm{C}$, to evaluate if hydrophobic interactions were involved in floc

371 formation. As shown in Table 6, there was a small but definite increase $(\mathrm{P}<0.05)$ in the turbidity 372 of the A to D samples on heating, which indicated that heat-induced partial or full denaturation 373 of the protein exposed additional polyphenol binding sites. This was confirmed by the 374 corresponding slight increase in concentrations of dye-binding protein on heating (Table 6). 375 Although this protein increase was not always significantly different, the trend was always to 376 increase protein on heating. Heating to increase floc formation is also consistent with a greater 
377 role for hydrophobic rather than hydrogen bonding. ${ }^{26}$ This is because hydrophobic groups, i.e., 378 from hydrophobic proline, tend to be concentrated in the interior of water-soluble proteins, it is 379 likely that more hydrophobic (polyphenol) bonding sites were exposed by the heating as protein 380 hydrogen bonds are broken with the heat. ${ }^{26}$ Heating has similarly been shown to increase the 381 hydrophobicity of ovalbumin and lysozyme proteins. ${ }^{29}$ In this study, the heating of the flocs 382 (60\% ABV samples) to $80{ }^{\circ} \mathrm{C}$ not only consistently increased floc formation but also tended to 383 create some larger floc particles with an example shown in Figure 4. This is further strong 384 evidence that protein is involved with the formation and aggregation of flocs. During sugar 385 processing at both the factory and refinery, proteins have been exposed to temperatures $>80{ }^{\circ} \mathrm{C}$ 386 for prolonged periods and have been presumed to be thoroughly denatured. On the other hand, 387 high temperature (HT) stable amylases added in the factory to control starch have been found to 388 still be active in refined sugars indicating full denaturation does not always occur. ${ }^{23}$ The re389 heating dextranase to 80 and $100{ }^{\circ} \mathrm{C}$ for 30 min created up to $\sim 800$-fold more floc compared to 390 the non-heated dextranase (Table 4) although heating at $100{ }^{\circ} \mathrm{C}$ was worse than $80{ }^{\circ} \mathrm{C}$. Thus $>80$ ${ }^{\circ} \mathrm{C}$ temperatures caused too much heat denaturation and destroyed some of the polyphenol 392 binding sites. Heating the IT amylase to $80{ }^{\circ} \mathrm{C}$, however, created less binding to polyphenols and 393 was even worse at $100{ }^{\circ} \mathrm{C}$ (Table 4). Unlike the IT Amylase, the HT amylase generally 394 increased bounding to TA when it was pre-heated at $80{ }^{\circ} \mathrm{C}$ but this was reduced at $100{ }^{\circ} \mathrm{C}$. 395 Therefore, the heat-stability of the amylase protein affects alcohol floc formation. Overall, the 396 results in Table 6, further suggest proteins in refined sugars are not always completely denatured 397 as previously considered, but further studies are needed to confirm this.

398 The type of bonding involved in the floc formation was further probed by investigating the 399 effect of adding polar, non-polar, and ionic solvents (Table 7). Since the initial protein- 
400 polyphenol interaction is considered reversible ${ }^{26}$ it should be possible to dissolve already-formed 401 floc in DMF (a hydrogen bond acceptor) and dioxane (non-polar) solvents. As shown in Table 7, 402 all the flocs in the initial 60\% ABV samples were progressively dissolved by dioxane and 403 particularly DMF, although not all the flocs were dissolved in $40 \%$ of the solvent. Dissolution

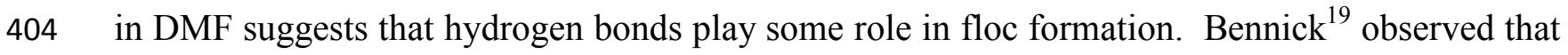
405 hydrogen bonds as well as hydrophobic effects are involved in polyphenolic/protein interactions. 406 Water aliquots added in the same proportions of the other solvents also caused a decline in 407 haze most likely because of dilution as the flocs dissolved in this polar solvent. Thus the 408 components of the floc are water soluble. The solubility of proteins in aqueous solutions 409 depends on the distribution of hydrophilic and hydrophobic amino acid residues on the protein 410 surface. As stated earlier, hydrophobic residues predominantly occur in the globular protein 411 core.

412 In comparison to the solvent water, all the cane invert sugars dissolved even further in the 413 ionic sodium chloride solution. Hagerman and Butler ${ }^{30}$ previously reported that ionic interaction 414 between proteins and polyphenols is considered to be of little or no importance and Bennick ${ }^{19}$ 415 reported there was little evidence that covalent bonding is involved. Furthermore, Asano et al. 416 (1982) reported that, in acidic conditions, such as $\mathrm{pH} 4.5$ in alcoholic drinks sweetened with 417 sugar, hydroxyl groups of polyphenols have no charge and, therefore, ionic bonding is not 418 involved in the floc formation mechanism. Therefore, the sodium chloride most likely allowed 419 more floc to dissolve because it altered the dielectric constant of the solvent. In strong contrast, 420 ethanol, a miscible solvent, is known to decrease the dielectric constant of water which in turn 421 allows proteins to come close together and eventually precipitate, i.e., desolubilize the protein. 422 Moreover, at high concentrations such as in this study, ethanol accelerates the denaturation of 
423 protein by disrupting hydrophobic interactions between amino acids. These reasons most likely

424 explain why the cane invert sugars produced even more haze on the addition of 10 to $40 \%$

425 ethanol (Table 7). This was also further evidenced by cane invert sugar A which contained more

426 protein than the other sugars, exhibiting the greatest increase in haze with ethanol addition (see

427 Table 2).

428 The solution $\mathrm{pH}$ is also known to often influence how proteins behave by affecting the net 429 charge of the protein molecules. This can lead to more or less ionization, with a change in ionic 430 attraction or repulsion which may also alter the protein solubility or the molecular 431 conformation. ${ }^{10}$ This in turn may influence the accessibility of the sites on the protein to which 432 the polyphenols can bind. Many alcoholic beverages are between $\mathrm{pH} 3.0$ and 4.0. At such acidic $433 \mathrm{pH}$, the proteins in the cane samples will be positively charged. ${ }^{4}$ Generally, it has been found that 434 the binding affinity of proteins for polyphenols and the precipitation of polyphenol complexes is $435 \mathrm{pH}$ dependent, with the greatest precipitation occurring near the isoelectric point of the protein 436 due to the decreased electrostatic repulsion of protein molecules at this $\mathrm{pH} .{ }^{19,30}$ The cane invert 437 sugars provided by the beverage manufacturer were acidic (see Table 2) but not adjusted for $\mathrm{pH}$. 438 At such acidic $\mathrm{pH}$, the proteins in the cane sugars will be positively charged, ${ }^{4}$ thus more studies 439 are now warranted on the effects of $\mathrm{pH}$.

440 Critical Concentrations and Ratios of Components for Floc Formation. Polyphenols are 441 thought to be multivalent ligands and may form crosslinks with two or more protein molecules. 442 They can cause structural and conformational changes of the protein. De Freitas and Mateus ${ }^{31}$ 443 showed that the protein binding affinity depends on the molecular size of the polyphenol 444 molecule, with the higher the molecular size the greater the tendency to interact with proteins. 445 McMurrough et al. ${ }^{32}$ showed that the concentration of polyphenol proanthocyanidin dimers of 
446 catechin and/or epicatechin were closely related to the rate of chill haze formation in beets. Thus

447 the stoichiometry and size of the polyphenol-protein complexes depends on the concentrations as 448 well as the reactants and protein/polyphenol ratio. ${ }^{26}$ As the beet invert sugar (control) in this 449 study which formed no floc still contained very low amounts of protein $(0.041 \mu \mathrm{g} / \mathrm{mL})$ and 450 polyphenols (I.V. 1.05) (see Table 3), there are most likely critical concentrations of protein and 451 polyphenols both individually and in relation to one another. An excess of one component may 452 change the interaction, but further studies are needed on this.

Mechanism of Floc Formation. The results presented in this paper have allowed a tentative mechanism for the formation of floc in alcohol beverages sweetened with cane sugars to be 455 advanced, which is illustrated in Figure 5. If critical concentrations of polyphenolic I.V. color compounds and denatured protein with polyphenol binding sites are available, they interact to 457 form a floc of colloidal size that causes light scattering. Additional heating of the floc can cause 458 aggregation. Eventually the floc particle reaches such a large size that it precipitates and may co-precipitate with other colloidal species such as dextran and, if present, other polysaccharides

460 rendered insoluble in the ethanol solvent. These other colloidal species may be entrained on the 461 floc molecules. Overall the initial floc interaction is dependent on hydrophobic and hydrogen 462 bonding.

Practical Solutions to Floc Problems. Dunsmore et al. ${ }^{33}$ reported that acid beverage floc

464 forming compounds found in refined sugars could be removed with select refining processes, but 465 they were unable to explain why they worked. Results in this study can now explain these 466 differences. Phosphatation clarification of refinery liquors incorporates the addition of ionic 467 (cationic) flocculants. As results in this study have shown that the floc forming interaction is not 468 based on ionic bonding but on hydrophobic and hydrogen bonding, the ionic flocculants would 
469 not have been able to remove the floc components. Carbonatation clarification incorporates

470 lesser amounts of ionic flocculants and also has a more inherent filtration system compared to

471 phosphatation clarification and thus was more likely able to remove the protein floc component.

472 Dunsmore et al. ${ }^{33}$ also reported that refinery liquors filtered through membranes of $0.60,0.80$, 473 and $1.20 \mu \mathrm{m}$ pore sizes at temperatures $<60{ }^{\circ} \mathrm{C}$ rendered them floc-less (floc negative) whereas

474 those filtered at $80{ }^{\circ} \mathrm{C}$ still formed flocs. Liquors filtered through a $0.45 \mu \mathrm{m}$ membrane were 475 floc-less even at $80{ }^{\circ} \mathrm{C}$. The results presented in this study can also explain these temperature 476 results. As shown in Table 6, on heating floc solutions to $80{ }^{\circ} \mathrm{C}$ there was a definite increase in 477 floc (haze) formation because heating exposes hydrophobic groups concentrated in the interior of 478 the water-soluble protein which are polyphenol bonding sites, causing more flocs to form. ${ }^{26}$ 479 Thus, at $80{ }^{\circ} \mathrm{C}$ - a common temperature in a sugar refinery, protein was further denatured and 480 floc formed. Because the small $0.45 \mu \mathrm{m}$ membrane rendered the liquor floc-less this gave an 481 indication of the physical size of the protein, however, membranes on an industrial scale are not 482 widely used as they become clogged easily.

483 An alternative practical solution to removing floc components is the use of active carbon. 484 Eggleston et al. $^{34}$ undertook laboratory studies with powdered activated carbon (PAC) and 485 demonstrated that powdered activated carbon removed amylase protein from refinery liquors 486 after phosphatation clarification, and the PAC also preferentially removed polyphenolic and 487 flavonoid colorants. This confirmed the research by Paton and Smith, ${ }^{35}$ who used 488 chromatography profiles to show that granular activated carbon was capable of removing all 489 polyphenolic and flavonoid colorants from refinery liquor whereas ion exchange resins and bone 490 char were not. Therefore, granular activated carbon, used in many sugar refineries as a 
491 decolorizing process, or powdered activated carbon could be very useful in removing the 492 components involved in floc formation, and more studies are now warranted.

493

494 ABBREVIATIONS USED

495 I.V. Indicator value (ratio of color at $\mathrm{pH} 9.0$ /color at $\mathrm{pH} 4.0$ )

496 ABF Acid beverage floc

497 ISP Indigenous cane polysaccharide

498 ICUMSA International Commission for Uniform Methods in Sugar Analyses

499 ABV Alcohol beverage volume

$500 \quad$ NTU Nephelometer turbidity units

501 DMF Dimethyl formamide

502 IC-IPAD Ion chromatography with integrated pulsed amperometric detection

503 Pro Proline

504 BSA Bovine serum albumen

505 TA Tannic acid

506 PAC Powdered activated carbon 
The authors thank Mr. Eldwin St. Cyr for excellent technical assistance and Dr. Barry Hurlbert

510 of USDA-ARS-SRRC for help with the protein assays. Mention of trade names or commercial

511 products in this article is solely for the purpose of providing specific information and does not

512 imply recommendation or endorsement by the U.S. Department of Agriculture. USDA is an 513 equal opportunity provider and employer.

514 FUNDING None

\section{REFERENCES}

516 (1) Edye, L. Sugar quality in soft drink manufacture: The acid beverage floc problem. In: 517 Shaidi F, Spanier A, Ch Ho., Braggins T (eds) Quality of Fresh and Processed Foods. Kluwer 518 Academic/Plenum Publishers, New York, 2004, 317-326.

519 (2) Cohen, M.A.; Dionisio, D.G.; Drescher, S. J. The isolation and characterization of certain 520 impurities responsible for quality problems in refined cane sugar. Proc. Sugar Indust. Technol. 521 1970, 123-165.

522 (3) Iciek, J.; Blaszcyk, I.; Biernasiak, J.; Lisik, K.; Wojtczak, M. Floc in acidified solutions 523 of white sugar - a literature review. Zuckerindustrie 2012, 137, 449-453.

524 (4) Clarke, M.A.; Roberts, E.J.; Godshall, M.A.; Carpenter, F. G. Beverage floc and cane 525 sugar. Internat. Sugar J. 1978, 80, 197-202.

526 (5) Naidoo, Y.; Simpson, R. The detection of protein in refined sugar. Proc S. Afr. Sugar 527 Technol Assoc. 2004, 78, 569-572.

528 (6) Lemos, L. R.; Nogueeira, A.; Wosiacki, G.; Lacerda, L. G; Demiate, I. M. The influence 529 of different amounts of dextran and starch in crystallized sugar in the formation of floc in acidic 530 carbonated solutions and alcoholic solutions. Sugar Tech 2013, 15, 65-70. 
531

532

533

534

535

536

537

538

539

540

541

542

543

544

545

546

547

548

549

550

551

552

(7) McKee, M.; Triche, R.; Godshall, M. A.; Richard, C. Floc prediction in refined white cane sugar: The SPRI Rapid Floc Test. Proc. SPRI Conf, 2010, 28-31.

(8) Smith, P.; Paton, N. H. Sugarcane flavonoids. Sugar Technologv Reviews 1985, 12, 117 142.

(9) Duarte-Almeida, J.M.; Salatino, A.; Genovese, M. I.; Lajolo, F. M. Phenolic composition and antioxidant activity of culms and sugarcane (Saccharum officinarum L.) products. Food Chem. 2011, 125, 660-664.

(10) Siebert, K. J.; Carrasco, A.; Lynn, P. Y. Formation of protein-polyphenol haze in beverages. LAgric Ed.Chem. 1996, 44, 1997-2005.

(11) Cole, M.; Eggleston, G.; Gilbert, A.; Chung, Y. Development of an analytical method to measure insoluble and soluble starch in sugarcane and sweet sorghum products. Food Chem. 2016, 190, 50-59.

(12) Bradford, M. M. A rapid and sensitive method for the quantitation of microgram quantities of protein utilizing the principle of protein-dye binding. Anal. Biochem. 1976, 72, $248-254$.

(13) Eggleston, G.; Borges, E. The multiple applications of ion chromatography oligosaccharide fingerprint profiles to solve a variety of sugar and sugar-biofuel industry problems. J.Agric. Fd.Chem. 2015, 63, 2841-2851.

(14) Chapon, L. Nephelometry as a method for studying the relations between polyphenols and proteins. L.Inst. Brew. 1993, 99, 49-56.

(15) Deitz, V.; Carpenter, F.; Rieger, C.; Rootare, H. The influence on pH on some properties of char liquors. Bone Char Research Project Tech. Report, 1959, No. 53. 
554 Source-to-Sink System. Elsevier, Amsterdam, 1973.

555 (17) Asano, K.; Shinagawa, K; Hashimoto, N. Characterization of haze-forming proteins of 556 beer and their roles in chill haze formation. J.Am. Soc. Brew. Chem. 1982, 40, 147-154.

557 (18) Bohin, M.C.; Vincken, J.P.; van der Hijden, H.T.; Gruppen, H. Efficacy of food proteins 558 as carriers of flavonoids. L.Agric. Ed.Chem. 2012, 60, 4136-4143.

559 (19) Bennick, A. Interaction of plant polyphenols with salivary proteins. Crit. Rev. Oral Biol. $560 \quad$ Med. 2002, 13, 184-196.

561 (20) Dufour, C.; Dangles, O. Flavonoid-serum albumin complexation: Determination of 562 binding constants and binding sites by fluorescence spectroscopy. Biochim. Biophys. Acta 2005, $5631721,164-173$.

564 (21) Asakura, T.; Adachi, K.; Schwartz, E. Stabilizing effect of various organic solvents on 565 protein. J.Biol.Chem. 1978, 253, 6423-6425.

566 (22) Richard, T.; Vitrac, X.; Merillon, J.M.; Monti, J.P. Role of peptide primary sequence in 567 polyphenol-protein recognition: An example with neurotensin. Biochim. Biophys. Acta 2005, $5681726,238-243$.

569 (23) Eggleston, G.; Gober, J.; St. Cyr, E. Development of an industrial method to 570 quantitatively measure carry-over amylase activity in raw and refined sugars. Internat. Sugar J. 571 2013, 115, 123-131.

572 (24) Hattori, A.; Ishibashi, K.; Minato, S. The purification and characterization of the 573 dextranase of Chaetomium gracile. Agric. Biol. Chem. 1981, 45, 2409-2416. 
574

575

576

577

578

579

580 581

582

583 584

(25) Kuhn, H.; Fietzek, P.; Lampen, J. N-Terminal amino acid sequence of Bacillus licheniformis a-Amylase: Comparison with Bacillus amyloliquefaciens and Bacillus subtilis enzymes. L. Bacteriol. 1982, 149, 372-373.

(26) Siebert, K. J.; Troukhanova, N. V.; Lynn, P.Y. Nature of poly-phenol-protein interactions. LAgric.Food Chem. 1996, 44, 80-85.

(27) Rafa Mohd Hafidz, R.N.; Yaakob, C.M.; Amin, I.; Noorfaizan, A. Chemical and functional properties of bovine and porcine skin gelatin. Internat. Food Res. J. 2011, 18, 813817.

(28) Gallo, M.; Vinci, G.; Graziani, G.; De Simone, C.; Ferrana, P. The interaction of cocoa polyphenols with milk proteins studied by proteomic techniques. Food Res. Internat. 2013, 54, $406-415$.

(29) Kato, A.; Fujimoto.K.; Matsudomi, N.; Kobayashi, K. Protein flexibility and functional properties of heat-denatured ovalbumin and lysozyme. Agric. Biol. Chem. 1986, 50, 417-420.

(30) Hagerman, A. E.; Butler, L. G. Protein precipitation method for the quantitative determination of tannins. LAsric. Food Chem. 1978, 26, 809-812.

(31) De Freitas, V.; Mateus, N. Structural features of procyanidin interactions with salivary proteins. LAgric. Fd. Chem. 2001, 49, 940-945.

(32) McMurrough, I.; Kelly, R.; Byrne, J. Effect of the removal of sensitive proteins and proanthocyanidins on the colloidal stability of beer. $L$ Am. Soc.Brew. Chem. 1992, 50, 67-76.

(33) Dunsmore, A.; Heal, M. J.; Matic, M.; Rugggas, F. M. A practical solution to the acid beverage floc problem. Proc. Sugar Indust. Technol. Mtg, 1978, 514-527. 
595

596

597

598

599

600

601

602

603

604

605

606

607

608

609

610

611

612

613

614

615

616

617

618

619

620

621

01

2

3

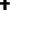

5

607

08

9

10

11

12

13

14

15

16

17

18

(34) Eggleston, G.; Vawda, A.; Zatlokovicz, J.; Lima, I.; E. St. Cyr. Use of activated carbons to remove undesirable residual amylase from factory and refinery streams. Proc. Sugar Industry Technol. Mtg, Canada, 2014, LXXIII, 330-342.

(35) Paton, N. H.; Smith, P. A HPLC study of the changes in colorant composition following factory decolorisation of raw liquors with bone char, resin and granular carbon. Proc. Sugar Proc. Res. Conf. 1982, 1-23.

\section{FIGURE CAPTIONS}

21


622 Figure 1. IC-IPAD oligosaccharide chromatograms of unfiltered $60 \%$ ABV solutions A to D. 623

624

625

Figure 2. Relationship between floc formation (haze) and the color indicator values (color at $\mathrm{pH}$

626 9.0/color at $\mathrm{pH} 4.0$ ) for initial invert sugars $\mathrm{A}$ to $\mathrm{G}$ (see Tables 2 and 3).

627

628

629

Figure 3. Relationship between floc formation (haze) and the protein concentrations for initial unfiltered $60 \%$ ABV solutions produced from invert sugars A to G (see Tables 2 and 3). Not

630 enough sample from invert sugar B was available for protein analyses.

Figure 4. Particle size distribution graphs for unfiltered $60 \%$ ABV solutions produced with cane 633 invert sugar A at (upper graph) $25^{\circ} \mathrm{C}$ and (lower graph) $80{ }^{\circ} \mathrm{C}$ for $30 \mathrm{~min}$.

Figure 5. Tentative mechanism for floc formation in alcohol beverages sweetened with refined

636 cane sugar. Most of the interactions are based on hydrophobic and hydrogen bonding. Colloidal

637 species such as dextran, starch, and silica may be entrained or co-precipitated with the floc.

638 Precipitation of floc also occurs without heating the floc. 
639 Table 1. Haze (NTU), Brix (\% dissolved refractometric solids), and pH of initial invert 640 sugars, non-filtered (floc formed) alcohol solutions, and filtered alcohol solutions.*

\begin{tabular}{|l|c|c|c|c|}
\hline \multicolumn{1}{|c|}{ Sample } & $\begin{array}{c}\text { Flocs } \\
\text { Present }\end{array}$ & $\begin{array}{c}\text { Brix } \\
\text { \% }\end{array}$ & pH & $\begin{array}{c}\text { Turbidity } \\
\text { (NTU) }\end{array}$ \\
\hline Invert Sugar A & $\mathrm{x}$ & 77.36 & 3.85 & 0.020 \\
Invert Sugar B & $\mathrm{x}$ & 72.22 & 3.55 & 0.018 \\
Invert Sugar C & $\mathrm{x}$ & 71.80 & 5.77 & 0.020 \\
Invert Sugar D & $\mathrm{x}$ & 76.47 & 4.93 & 0.024 \\
\hline $\begin{array}{l}\text { Unfiltered 60\% ABV } \\
\text { Solution A }\end{array}$ & $\checkmark$ & 33.42 & 5.33 & 19.30 \\
$\begin{array}{l}\text { Unfiltered 60\% ABV } \\
\text { Solution B }\end{array}$ & $\checkmark$ & 32.64 & 5.09 & 14.84 \\
$\begin{array}{l}\text { Unfiltered 60\% ABV } \\
\text { Solution C }\end{array}$ & $\checkmark$ & 32.40 & 6.28 & 11.34 \\
$\begin{array}{l}\text { Unfiltered 60\% ABV } \\
\text { Solution D }\end{array}$ & $\checkmark$ & 33.22 & 5.60 & 0.024 \\
\hline $\begin{array}{l}\text { Filtered 60\% ABV } \\
\text { Solution A }\end{array}$ & $\mathrm{x}$ & 33.92 & 5.34 & 0.030 \\
$\begin{array}{l}\text { Filtered 60\% ABV } \\
\text { Solution B }\end{array}$ & $\mathrm{x}$ & 32.52 & 5.14 & 0.023 \\
$\begin{array}{l}\text { Filtered 60\% ABV } \\
\text { Solution C }\end{array}$ & $\mathrm{x}$ & 32.41 & 6.28 & 0.024 \\
$\begin{array}{l}\text { Filtered 60\% ABV } \\
\text { Solution D }\end{array}$ & $\mathrm{x}$ & 33.96 & 5.70 & \\
\hline
\end{tabular}


Table 2. Compositional analyses of initial invert sugars, non-filtered (floc formed) alcohol solutions, and filtered alcohol solutions.*

\begin{tabular}{|c|c|c|c|c|c|c|c|c|c|c|c|c|}
\hline Sample & $\begin{array}{l}\text { Insoluble } \\
\text { Starch } \\
\text { (ppm/Brix) }\end{array}$ & $\begin{array}{c}\text { Soluble } \\
\text { Starch } \\
\text { (ppm/Brix) }\end{array}$ & $\begin{array}{c}\text { Dextran } \\
\text { (ppm/Brix) }\end{array}$ & $\begin{array}{c}\text { Ash } \\
\%\end{array}$ & $\begin{array}{c}\text { Protein } \\
\quad \%\end{array}$ & $\begin{array}{c}\text { Fat } \\
\%\end{array}$ & $\begin{array}{c}\text { Color } \\
\text { at pH } \\
3.0 \\
\text { (ICU) } \\
\end{array}$ & $\begin{array}{c}\text { Color } \\
\text { at pH } \\
4.0 \\
(\text { ICU) } \\
\end{array}$ & $\begin{array}{c}\text { Color } \\
\text { at pH } \\
7.0 \\
\text { (ICU) } \\
\end{array}$ & $\begin{array}{c}\text { Color } \\
\text { at pH } \\
9.0 \\
(\text { ICU) } \\
\end{array}$ & $\begin{array}{l}\text { I.V. } \\
\text { 9.0/3.0 }\end{array}$ & $\begin{array}{l}\text { I.V. } \\
9.0 / 4.0\end{array}$ \\
\hline Invert Sugar A & 0 & 0 & 165.6 & $<0.1$ & 0.60 & 0.5 & 244.4 & 248.7 & 277.3 & 370.7 & 1.52 & 1.50 \\
\hline Invert Sugar B & 0 & 0 & n.d. ${ }^{\dagger}$ & $<0.1$ & n.d. ${ }^{\dagger}$ & 0.5 & 220.9 & 222.6 & 255.7 & 322.5 & 1.46 & 1.45 \\
\hline Invert Sugar C & 0 & 0 & 186.7 & 0.3 & 0.11 & 0.3 & 238.8 & 237.5 & 252.7 & 300.9 & 1.26 & 1.27 \\
\hline Invert Sugar D & 0 & 0 & 102.9 & $<0.1$ & 0.13 & 0.4 & 224.7 & 229.3 & 247.9 & 290.2 & 1.27 & 1.27 \\
\hline $\begin{array}{l}\text { Unfiltered } 60 \% \\
\text { ABV Solution A }\end{array}$ & 0 & 0 & 5.2 & $<0.1$ & 29.67 & $<0.1$ & 306.1 & 308.3 & 309.9 & 350.2 & 1.14 & 1.14 \\
\hline $\begin{array}{l}\text { Unfiltered } 60 \% \\
\text { ABV Solution B }\end{array}$ & 0 & 0 & n.d. ${ }^{\dagger}$ & $<0.1$ & n.d. ${ }^{\dagger}$ & $<0.1$ & 297.4 & 300.0 & 310.6 & 335.8 & 1.13 & 1.12 \\
\hline $\begin{array}{l}\text { Unfiltered } 60 \% \\
\text { ABV Solution C }\end{array}$ & 0 & 0 & 4.5 & $<0.1$ & 29.73 & $<0.1$ & 319.4 & 317.7 & 325.3 & 349.5 & 1.09 & 1.10 \\
\hline $\begin{array}{l}\text { Unfiltered } 60 \% \\
\text { ABV Solution D } \\
\end{array}$ & 0 & 0 & 0 & $<0.1$ & 25.79 & $<0.1$ & 290.2 & 296.4 & 300.5 & 301.2 & 1.08 & 1.07 \\
\hline $\begin{array}{l}\text { Filtered } 60 \% \\
\text { ABV Solution A }\end{array}$ & 0 & 0 & n.d. & $<0.1$ & n.d. & $<0.1$ & 298.7 & 299.8 & 306.6 & 341.3 & 1.14 & 1.14 \\
\hline $\begin{array}{l}\text { Filtered } 60 \% \\
\text { ABV Solution B }\end{array}$ & 0 & 0 & n.d. & $<0.1$ & n.d. & $<0.1$ & 296.7 & 295.2 & 307.8 & 331.5 & 1.12 & 1.12 \\
\hline $\begin{array}{l}\text { Filtered } 60 \% \\
\text { ABV Solution C }\end{array}$ & 0 & 0 & n.d. & $<0.1$ & n.d. & $<0.1$ & 319.8 & n.d. ${ }^{\ddagger}$ & 350.8 & 358.6 & 1.12 & n.d. ${ }^{*}$ \\
\hline $\begin{array}{l}\text { Filtered } 60 \% \\
\text { ABV Solution D }\end{array}$ & 0 & 0 & n.d. & $<0.1$ & n.d. & $<0.1$ & 321.4 & 299.2 & 297.9 & 319.9 & 1.07 & 1.07 \\
\hline
\end{tabular}

*All of these samples were provided by the North American alcoholic beverage manufacturer

All the invert sugars A to D and corresponding unfiltered $60 \% \mathrm{ABV}$ solutions were shown to qualitatively contain protein n.d. ${ }^{\dagger}=$ not determined because of insufficient sample

${ }^{*}$ n.d. $=$ not determined as anomalous 
Table 3. Compositional analyses of initial invert sugars $\mathbf{E}$ to $\mathbf{G}$ and beet invert sugar (control) as well as their corresponding unfiltered (floc formed) alcohol solutions.* Invert sugars E, F, and G, formed flocs of 16.8, 10.4, and 14.4 NTU, respectively, in the unfiltered $60 \%$ ABV solutions. The beet invert sugar did not form visible floc $(0.059 \mathrm{NTU})$ when in the unfiltered $60 \%$ ABV solution.

\begin{tabular}{|c|c|c|c|c|c|c|c|c|c|c|c|}
\hline Sample & $\begin{array}{l}\text { Insoluble } \\
\text { Starch } \\
\text { (ppm/Brix) }\end{array}$ & $\begin{array}{l}\text { Soluble } \\
\text { Starch } \\
\text { (ppm/Brix) }\end{array}$ & $\begin{array}{c}\text { Dextran } \\
\text { (ppm/Brix) }\end{array}$ & $\begin{array}{l}\text { Qual. } \\
\text { Protein }\end{array}$ & $\begin{array}{l}\text { Quant. } \\
\text { Protein } \\
(\mu \mathrm{g} / \mathrm{mL})\end{array}$ & $\begin{array}{c}\text { Color } \\
\text { at pH } \\
3.0 \\
(\mathrm{ICU})\end{array}$ & $\begin{array}{c}\text { Color } \\
\text { at pH } \\
4.0 \\
(\text { ICU) }\end{array}$ & $\begin{array}{c}\text { Color } \\
\text { at pH } \\
7.0 \\
\text { (ICU) }\end{array}$ & $\begin{array}{c}\text { Color } \\
\text { at pH } \\
9.0 \\
(\mathrm{ICU})\end{array}$ & $\begin{array}{l}\text { I.V. } \\
9 / 3\end{array}$ & $\begin{array}{l}\text { I.V. } \\
9 / 4\end{array}$ \\
\hline Invert Sugar E & 0 & 0 & 136.6 & $\checkmark$ & 0.250 & 236.9 & 246.9 & 271.7 & 360.6 & 1.52 & 1.46 \\
\hline Invert Sugar F & 0 & 0 & 116.0 & $\checkmark$ & 0.150 & 239.9 & 241.8 & 255.2 & 289 & 1.20 & 1.20 \\
\hline Invert Sugar G & 0 & 0 & 129.5 & $\checkmark$ & 0.330 & 239.2 & 240.8 & 249.8 & 294.6 & 1.23 & 1.22 \\
\hline $\begin{array}{l}\text { Beet Invert } \\
\text { Sugar (control) }\end{array}$ & 0 & 0 & 27.3 & $\checkmark$ & 0.041 & 159.9 & 167.5 & 167.5 & 175.5 & 1.10 & 1.05 \\
\hline $\begin{array}{l}\text { Unfiltered } \\
60 \% \text { ABV } \\
\text { Solution E }\end{array}$ & 0 & 0 & 0 & $\checkmark$ & 34.80 & 301.0 & 296.2 & 316.7 & 342.0 & 1.4 & 1.15 \\
\hline $\begin{array}{l}\text { Unfiltered } \\
60 \% \text { ABV } \\
\text { Solution F }\end{array}$ & 0 & 0 & 0 & $\checkmark$ & 32.29 & 300.8 & 298.4 & 309.0 & 316.0 & 1.05 & 1.09 \\
\hline $\begin{array}{l}\text { Unfiltered } \\
60 \% \text { ABV } \\
\text { Solution G }\end{array}$ & 0 & 0 & 1.2 & $\checkmark$ & 30.48 & 304.5 & 295.9 & 313.1 & 320.4 & 1.05 & 1.05 \\
\hline $\begin{array}{l}\text { Beet Invert } \\
\text { Sugar (control) }\end{array}$ & 0 & 0 & 1.3 & $\checkmark$ & 25.69 & 291.5 & 297.1 & 302.4 & 302.0 & 1.04 & 1.02 \\
\hline
\end{tabular}

*All invert samples were provided by the North American alcoholic beverage manufacturer and the $60 \%$ ABV solutions were created in the laboratory ${ }^{\dagger}$ n.d. $=$ not determined

Table 4. Model solutions to show the effect of enzyme proteins, non pre-heated and pre-heated, on Haze (NTU) formation (average values shown) with tannic acid, after incubation at $25{ }^{\circ} \mathrm{C}$ for $30 \mathrm{~min}$.

\begin{tabular}{|l|l|l|l|l|l|l|l|l|l|}
\hline$\%$ & Dextranase & Dextranase & Dextranase & Intermed. & Intermed. & Intermed. & High & High & High \\
\hline
\end{tabular}




\begin{tabular}{|c|c|c|c|c|c|c|c|c|c|}
\hline $\begin{array}{l}\text { Final } \\
\text { Volume } \\
\text { Added }\end{array}$ & $\begin{array}{l}\text { Non Pre- } \\
\text { heated }\end{array}$ & $\begin{array}{c}\text { Pre-heated } \\
\text { to } \\
80^{\circ} \mathrm{C}\end{array}$ & $\begin{array}{c}\text { Pre-heated } \\
\text { to } \\
100^{\circ} \mathrm{C}\end{array}$ & $\begin{array}{l}\text { Temp. } \\
\text { Stable } \\
\text { Amylase* } \\
\text { Non Pre- } \\
\text { heated }\end{array}$ & $\begin{array}{c}\text { Temp. } \\
\text { Stable } \\
\text { Amylase* } \\
\text { Pre- } \\
\text { heated to } \\
80^{\circ} \mathrm{C} \\
\end{array}$ & $\begin{array}{c}\text { Temp. } \\
\text { Stable } \\
\text { Amylase* } \\
\text { Pre- } \\
\text { heated to } \\
100{ }^{\circ} \mathrm{C}\end{array}$ & $\begin{array}{c}\text { Temp. } \\
\text { Stable } \\
\text { Amylase }^{\dagger} \\
\text { Non Pre- } \\
\text { heated }\end{array}$ & $\begin{array}{c}\text { Temp. } \\
\text { Stable } \\
\text { Amylase }^{\dagger} \\
\text { Pre-heated } \\
\text { to } 80^{\circ} \mathrm{C}\end{array}$ & $\begin{array}{c}\text { Temp. } \\
\text { Stable } \\
\text { Amylase }^{\dagger} \\
\text { Pre-heated } \\
\text { to } 100{ }^{\circ} \mathrm{C}\end{array}$ \\
\hline 0 & 0.026 & 0.026 & 0.026 & 0.023 & 0.023 & 0.023 & 0.026 & 0.026 & 0.026 \\
\hline 0.1 & 0.097 & 25.9 & 21.4 & 19.6 & 8.2 & 2.8 & 37.6 & 58.4 & 36.0 \\
\hline 0.75 & 1.830 & 168.0 & 127.0 & 199.0 & 81.0 & 21.2 & 313.0 & 373.3 & 320.0 \\
\hline 1.0 & 4.120 & 145.0 & 128.0 & 194.0 & 21.0 & 21.0 & 349.0 & 274.7 & 308.0 \\
\hline
\end{tabular}

$\$$ The initial protein content of the non-heated enzymes were $0.281,2.235$, and $1.541 \%$ for dextranase, intermediate temperature stable 663 amylase, and high temperature stable amylase, respectively

$664 \square$ Dextranase enzyme is most active at $\sim 50{ }^{\circ} \mathrm{C}$ (Eggleston et al., 2007) and sourced from Chaetomium erraticum.

665 *Sourced from Bacillus amyloliquefaciens 
667 Table 5. Haze (NTU) resulting from the addition of haze-active gelatin protein or haze 668 active poly-phenolic tannic acid on unfiltered alcohol samples incubated at $25^{\circ} \mathrm{C}$ for 30 669 min.*

\begin{tabular}{|c|c|c|c|c|c|}
\hline $\begin{array}{c}\text { Additive } \\
\text { concentration } \\
\text { (ppm) }\end{array}$ & $\begin{array}{c}\text { De-ionized } \\
\text { Water }\end{array}$ & $\begin{array}{c}\text { Canada } \\
\text { (A) }\end{array}$ & $\begin{array}{c}\text { Mischprobe } \\
\text { (C) }\end{array}$ & $\begin{array}{c}\text { USA } \\
\text { (D) }\end{array}$ & $\begin{array}{c}\text { Beet } \\
\text { Invert Sugar }\end{array}$ \\
\hline \multicolumn{5}{|c|}{ Gelatin B } \\
\hline $\mathbf{0}$ & 0.032 & 16.9 & 13.6 & 9.8 & 0.101 \\
$\mathbf{2 5}$ & 0.041 & 16.5 & 15.7 & 8.5 & 0.125 \\
$\mathbf{1 0 0}$ & 0.035 & 16.3 & 17.4 & 8.2 & 0.125 \\
$\mathbf{5 0 0}$ & 1.61 & 13.4 & 11.3 & 7.3 & 0.116 \\
\hline \multicolumn{5}{|c|}{ Tannic Acid $^{\dagger}$} \\
$\mathbf{0}$ & nd & 16.9 & 13.6 & 7.6 & 0.068 \\
$\mathbf{1 0 0}$ & nd & 15.4 & 12.8 & 9.2 & 0.098 \\
$\mathbf{5 0 0}$ & nd & 14.7 & 12.7 & 9.2 & 1.210 \\
\hline
\end{tabular}

670

671

672

673

674

675

676

*The A, C, and D 60\% ABV samples were re-created in the USDA laboratory from the original invert sugars

Haze (NTU) values among the samples and additive concentrations were statistically different at the $5 \%$ probability level for all samples

${ }^{\dagger}$ The stock solution of tannic acid (5000 ppm) used to create the solutions was $0.063 \mathrm{NTU}$ nd $=$ not determined 
677 Table 6. Haze (NTU) resulting from the incubation of $60 \%$ ABV samples at 25 and $80{ }^{\circ} \mathrm{C}$ 678 and associated protein contents.

\begin{tabular}{|c|c|c|c|c|}
\hline $\begin{array}{l}\text { Unfiltered } \\
\text { alcohol solution }\end{array}$ & $\begin{array}{c}\text { Haze at } 25{ }^{\circ} \mathrm{C} \\
\text { NTU }\end{array}$ & $\begin{array}{c}\text { Haze at } 80{ }^{\circ} \mathrm{C} \\
\text { NTU }\end{array}$ & $\begin{array}{c}\text { Protein at } 25{ }^{\circ} \mathrm{C} \\
(\mu \mathrm{g} / \mathrm{mL})^{\dagger}\end{array}$ & $\begin{array}{c}\text { Protein at } 80{ }^{\circ} \mathrm{C} \\
(\mu \mathrm{g} / \mathrm{mL})\end{array}$ \\
\hline$A^{*}$ & $12.3^{t}$ & 14.2 & $29.67 \mathrm{a}$ & $29.93 \mathrm{a}$ \\
\hline $\mathbf{B}^{*}$ & 13.6 & 16.7 & $32.61 \mathrm{a}$ & $31.58 \mathrm{a}$ \\
\hline$C^{*}$ & 10.7 & 11.5 & $30.40 \mathrm{a}$ & $31.31 \mathrm{a}$ \\
\hline D* & 7.16 & 7.90 & $25.79 b$ & $29.17 \mathrm{a}$ \\
\hline $\begin{array}{l}\text { Beet invert sugar } \\
\text { (control) }\end{array}$ & 0.059 & 0.066 & $25.69 b$ & $30.75 a$ \\
\hline $\begin{array}{l}\text { Analytical grade } \\
\text { sucrose (control) }\end{array}$ & 8.49 & 8.26 & $26.9 a$ & $27.64 a$ \\
\hline
\end{tabular}

$679 *$ The A to D 60\% ABV samples were re-created in the USDA laboratory from the original invert sugars. Initial Haze (NTU) values are lower because they had not been left as long to form as the original samples (see Table 1).

$682 \dagger$ Based on the Bradford dye-binding protein assay

$683{ }^{\ddagger}$ Haze (NTU) values at 25 and $80{ }^{\circ} \mathrm{C}$ were statistically different at the $5 \%$ probability level for all 684 samples

$685 \square$ Values followed by the same lower case letter were not significantly different at the $5 \%$ 686 probability level between the two samples at the two temperatures

687

688

689

690

691

692

693

694

695

696

697

698

699

700

701

702 
Table 7. Effect of various concentrations of polar and non-polar solvents on Haze (NTU) formation or dissolution on unfiltered $60 \% \mathrm{ABV}$ samples incubated at $25^{\circ} \mathrm{C}$ for 30 min.*

\begin{tabular}{|c|c|c|c|c|c|}
\hline $\begin{array}{l}\text { \% Final } \\
\text { Volume } \\
\text { Added }\end{array}$ & Water & Ethanol & Dioxane & DMF & $\begin{array}{c}20 \% \\
\text { Sodium } \\
\text { Chloride } \\
\text { Solution } \\
\end{array}$ \\
\hline Polarity: & Very Polar & $\begin{array}{l}\text { Low polar \& } \\
\text { low non- } \\
\text { polar }\end{array}$ & Non-polar & $\begin{array}{c}\text { Polar } \\
\text { (hydrogen } \\
\text { bond } \\
\text { acceptor) }\end{array}$ & Ionic \\
\hline \multicolumn{6}{|c|}{ Canada (A) } \\
\hline $\mathbf{0}$ & 16.2 & 16.2 & 16.2 & 16.2 & 16.2 \\
\hline 10 & 11.3 & 16.7 & 14.4 & 13.0 & 13.2 \\
\hline 20 & 11.5 & 21.1 & 13.9 & 12.5 & 9.8 \\
\hline 40 & 7.2 & 21.1 & 12.9 & 9.8 & 5.3 \\
\hline \multicolumn{6}{|c|}{ Mischprobe (C) } \\
\hline $\mathbf{0}$ & 12.6 & 12.6 & 12.6 & 12.6 & 12.6 \\
\hline 10 & 10.2 & 12.2 & 11.2 & 11.3 & 10.0 \\
\hline 20 & 9.4 & 12.5 & 10.7 & 10.2 & 9.3 \\
\hline 40 & 5.9 & 12.9 & 9.2 & 8.4 & 5.1 \\
\hline \multicolumn{6}{|c|}{ USA (D) } \\
\hline $\mathbf{0}$ & 7.4 & 7.4 & 7.4 & 7.4 & 7.4 \\
\hline 10 & 6.2 & 7.4 & 6.8 & 6.2 & 4.6 \\
\hline 20 & 4.8 & 8.0 & 6.3 & 5.1 & 4.4 \\
\hline 40 & 3.7 & 8.4 & 6.0 & 5.0 & 2.7 \\
\hline \multicolumn{6}{|c|}{ Beet invert sugar } \\
\hline $\mathbf{0}$ & 0.072 & 0.072 & 0.072 & 0.072 & 0.072 \\
\hline 10 & 0.065 & 0.086 & 0.068 & 0.075 & 0.087 \\
\hline 20 & 0.021 & 0.091 & 0.087 & 0.093 & 0.088 \\
\hline 40 & 0.022 & 0.116 & 0.082 & 0.088 & 0.070 \\
\hline \multicolumn{6}{|c|}{ Analytical grade sucrose } \\
\hline $\mathbf{0}$ & 7.4 & 7.4 & 7.4 & 7.4 & 7.4 \\
\hline 10 & 6.9 & 7.6 & 6.9 & 6.5 & 6.3 \\
\hline 20 & 5.8 & 7.6 & 6.2 & 6.2 & 5.5 \\
\hline 40 & 5.8 & 9.8 & 6.7 & 5.6 & 4.2 \\
\hline
\end{tabular}

*The A, C, and D 60\% ABV samples were re-created in the USDA laboratory from the original invert sugars. Initial Haze (NTU) values are lower because they had not been left as long to form as the original samples (see Table 1).

Haze (NTU) values among the samples and additive concentrations were statistically different at the $5 \%$ probability level 


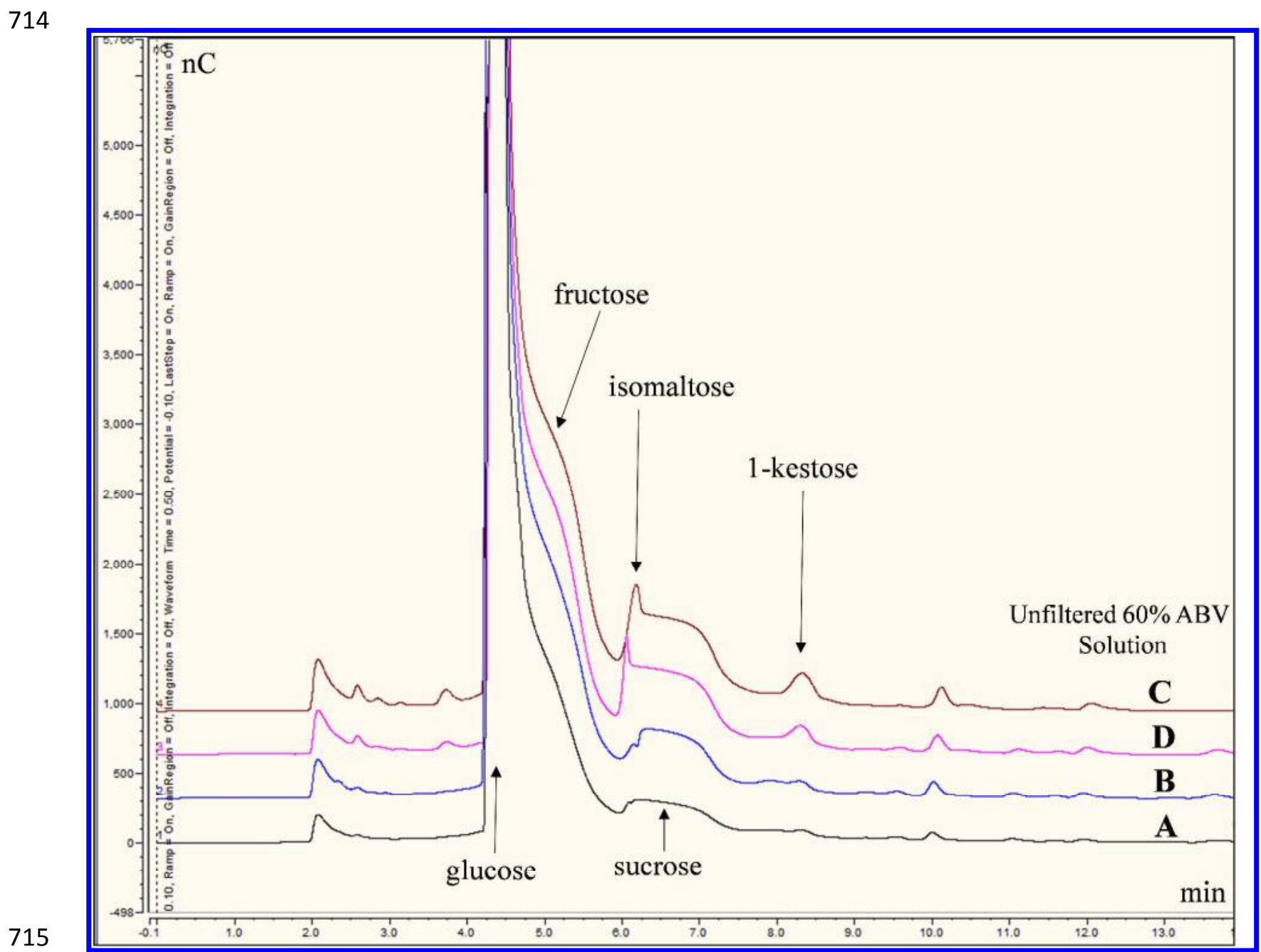

716

Figure 1.

717

718

719

720

721

722

723

724

725

726 


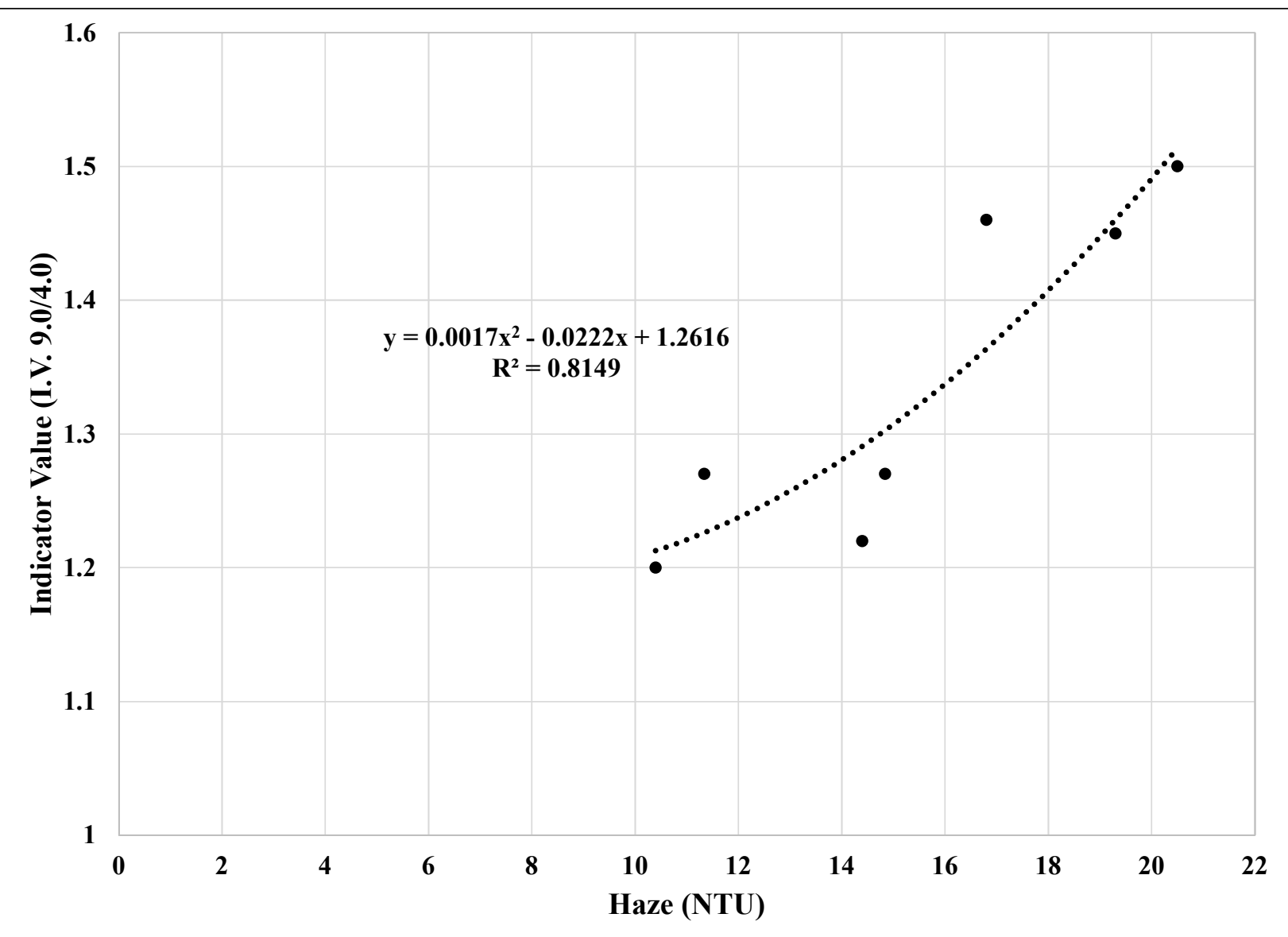

727

Figure 2.

729

730

731

732

733

734

735

736

737

738

739 


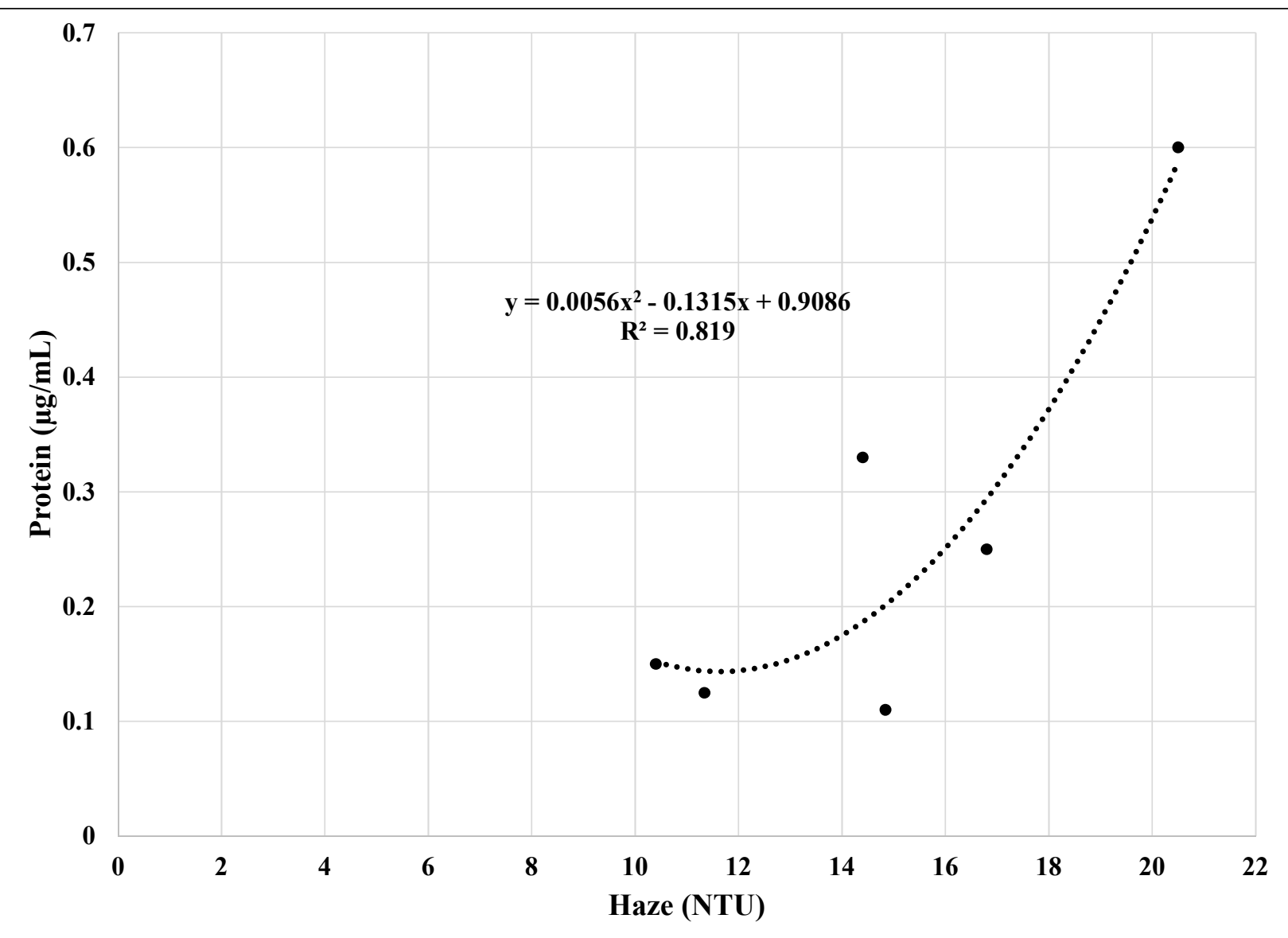

740

Figure 3.

742

743

744

745

746

747

748

749

750

751

752 

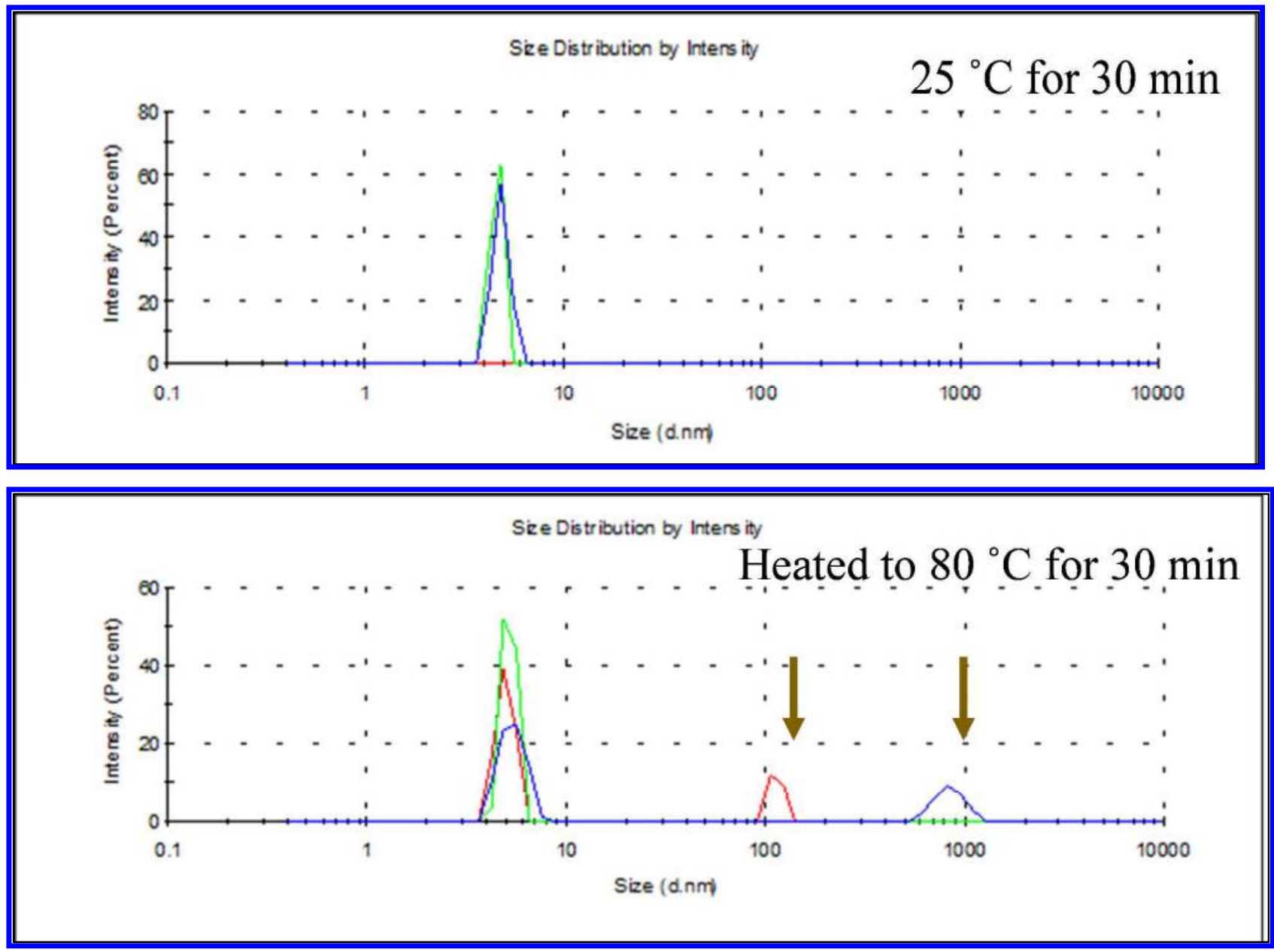

Figure 4. 
Tentative Mechanism for Floc Formation (mostly hydrophobic and hydrogen bond interactions)

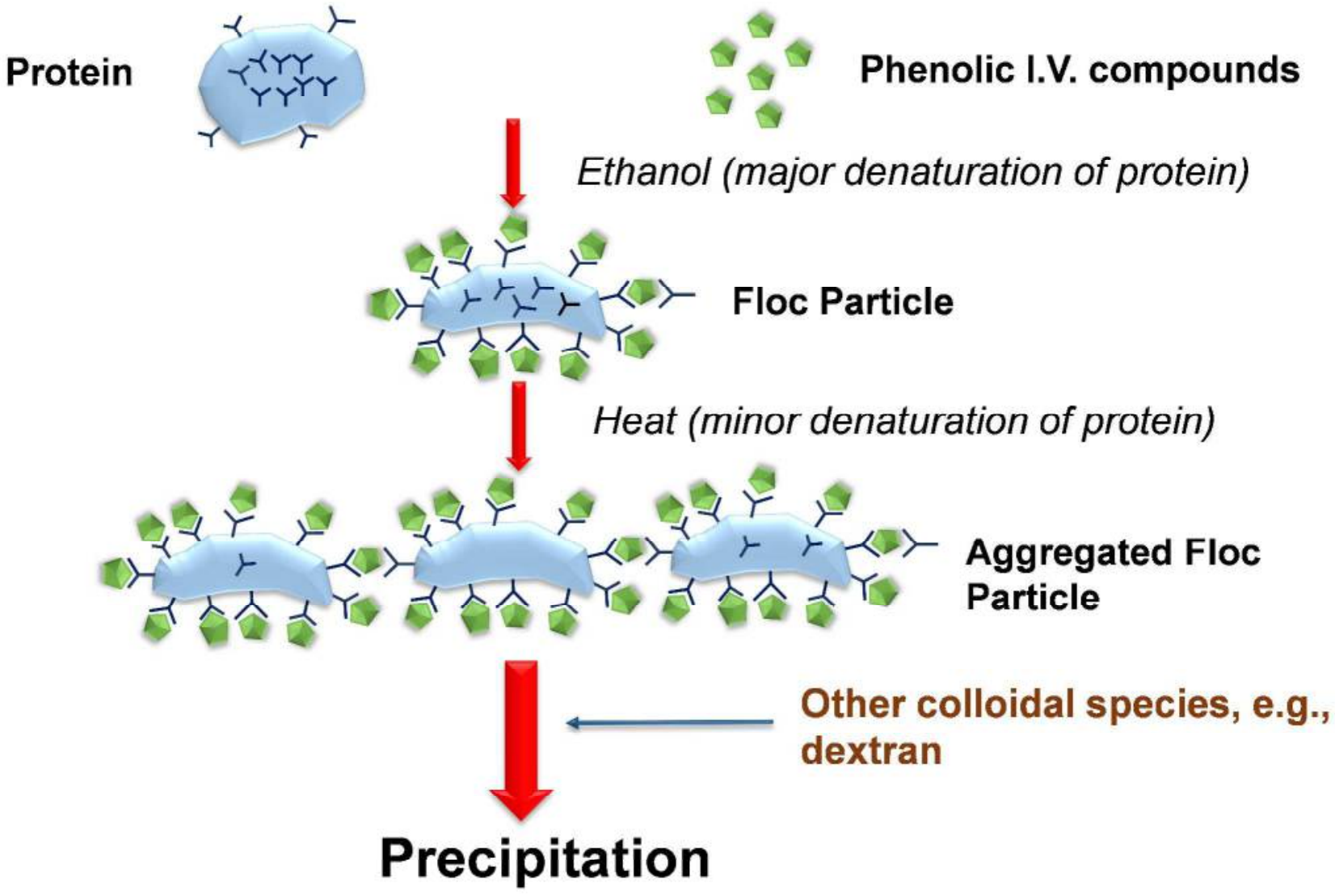

759 Figure 5. 


\section{For Table of Contents Only}

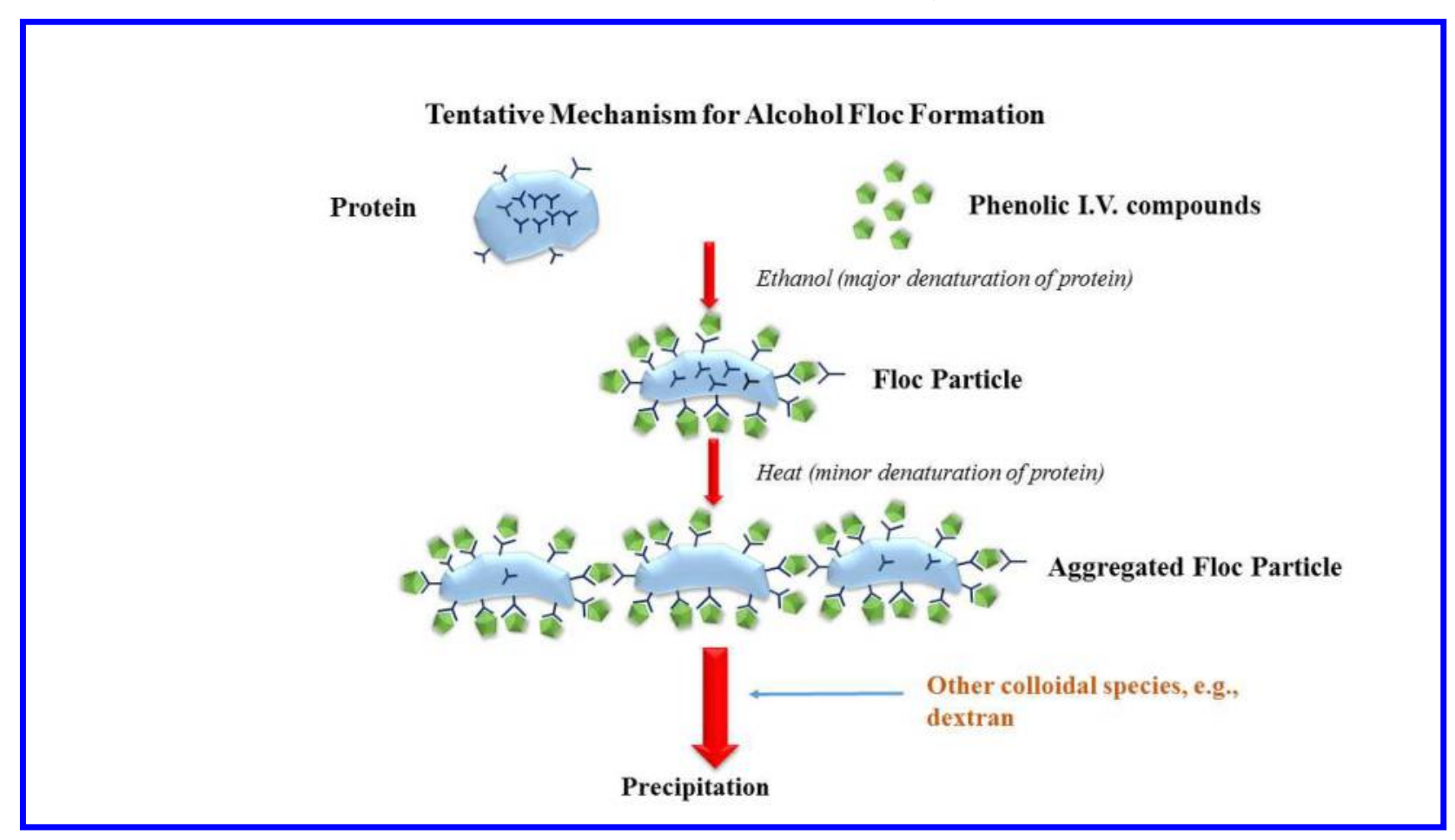

